\title{
Effect of delaying colostrum feeding on passive transfer and intestinal bacterial colonization in neonatal male Holstein calves
}

\author{
A. J. Fischer, ${ }^{*}$ Y. Song, ${ }^{*} Z$. He, ${ }^{*}$ D. M. Haines, †¥ L. L. Guan, ${ }^{*}$ and M. A. Steele ${ }^{* 1}$ \\ *Department of Agricultural, Food and Nutritional Science, University of Alberta, Edmonton, Alberta, Canada T6G 2P5 \\ †Western College of Veterinary Medicine, University of Saskatchewan, Saskatoon, Saskatchewan, Canada S7N 5B4 \\ $\ddagger$ The Saskatoon Colostrum Co. Ltd., Saskatoon, Saskatchewan, Canada S7K 6A2
}

\section{ABSTRACT}

The objective of this study was to investigate the effect of time of first colostrum feeding on the passive transfer of $\operatorname{IgG}$ and on bacterial colonization in the intestine of neonatal dairy calves. Twenty-seven male Holstein calves were randomly assigned to 1 of 3 treatments at birth: calves were fed colostrum at 45 $\min (0 \mathrm{~h}, \mathrm{n}=9), 6 \mathrm{~h}(\mathrm{n}=9)$, or $12 \mathrm{~h}$ after birth $(\mathrm{n}=$ 9). Calves were fed pooled, heat-treated colostrum (62 $\mathrm{g}$ of $\mathrm{IgG} / \mathrm{L}$ ) at their respective feeding times at $7.5 \%$ of birth body weight and fed milk replacer at $2.5 \%$ of birth body weight per meal every $6 \mathrm{~h}$ thereafter. Blood samples were taken every $3 \mathrm{~h}$ using a jugular catheter and were analyzed for determination of serum IgG by radial immunodiffusion. At $51 \mathrm{~h}$ after birth, calves were euthanized for collection of tissue and digesta of the distal jejunum, ileum, and colon. Quantitative real-time PCR was used to estimate the prevalence of Bifidobacterium spp., Lactobacillus spp., Fecalibacterium prausnitzii, Clostridium cluster XIVa, and total Escherichia coli. Delaying colostrum feeding by $6 \mathrm{~h}(35.6 \pm 1.88 \%)$ and $12 \mathrm{~h}(35.1 \pm 3.15 \%)$ decreased the maximum apparent efficiency of absorption of IgG compared with feeding colostrum immediately after birth $(51.8 \pm 4.18 \%)$ and delayed the time to maximum serum IgG concentration (24 h vs. $15 \mathrm{~h}$, respectively). Moreover, 12-h calves tended to have a lower prevalence of Bifidobacterium spp. $(0.12 \pm 0.017 \%)$ and Lactobacillus spp. (0.07 \pm $0.019 \%$ ) associated with the colon mucosa compared with 0 -h calves $(1.24 \pm 0.648 \%$ and $0.26 \pm 0.075 \%$, respectively). In addition, 6 -h $(0.26 \pm 0.124 \%)$ and 12 -h $(0.49 \pm 0.233 \%)$ calves had a lower prevalence of total E. coli associated with ileum mucosa compared with 0 -h calves $(1.20 \pm 0.458 \%)$. These findings suggest that delaying colostrum feeding within $12 \mathrm{~h}$ of life decreases the passive transfer of IgG and may delay the coloniza-

Received June 25, 2017.

Accepted November 27, 2017.

${ }^{1}$ Corresponding author: masteele@ualberta.ca tion of bacteria in the intestine, possibly leaving the calf vulnerable to infections during the preweaning period. Key words: passive transfer, neonatal calf, bacterial colonization

\section{INTRODUCTION}

Preweaning dairy calves are at high risk of morbidity and mortality, with recorded rates as high as 50\% and $11 \%$, respectively (USDA, 2007). Calves are born without passive immunity because the placenta of the cow separates the maternal and fetal blood supply, thus preventing the transfer of immunoglobulins during gestation (Godden, 2008). To protect the calf, the dam produces colostrum, which contains high levels of IgG in addition to nutrients and other bioactive factors. The termination of the absorption of macromolecules, including $\mathrm{IgG}$, across the gut epithelium is termed "gut closure" and is thought to occur by approximately $24 \mathrm{~h}$ postpartum in calves (Stott et al., 1979). The passive transfer of IgG across the small intestinal epithelium has been shown to be optimal within the first $4 \mathrm{~h}$ of life and rapidly declines after $12 \mathrm{~h}$ postpartum (Stott et al., 1979; Weaver et al., 2000). It is therefore generally accepted that calves fed colostrum immediately after birth will achieve higher maximum serum IgG concentrations than those fed colostrum more than 4 $\mathrm{h}$ after birth. Unfortunately, poor colostrum management continues to be a problem on dairy farms, with approximately $31 \%$ of mortality in the first 3 wk of life being due to failure of passive transfer of IgG (Wells et al., 1996). Multiple factors are responsible for insufficient circulating IgG, including feeding contaminated or low-quality colostrum and - of particular interest in the current study - the first ingestion of colostrum occurring more than $6 \mathrm{~h}$ after birth (Vasseur et al., 2010).

Successful passive transfer of IgG is generally perceived as an indicator of decreased risk of disease and mortality in the neonatal calf. Similarly, the early establishment of gut microbiota has been reported to be associated with reduced disease risk in calves (Oikonomou 
et al., 2013). For example, enterotoxigenic Escherichia coli is typically associated with an increased incidence of diarrhea, whereas beneficial species, such as Bifidobacterium, are associated with a healthy gut microbiome and immunity (Apgar et al., 1993; Picard et al., 2005; Uhde et al., 2008). The establishment of gut microbiota in the neonate is associated with the development of the mucosal immune system and secondary lymphoid structures, and certain bacterial genera are able to produce energy substrates for the intestinal epithelia (Guarner, 2006; Sommer and Bäckhed, 2013). Current knowledge of the commensal bacteria present in the calf microbiota and their effects on the host are limited. Variation of microbial composition in the rumen has been shown to be higher in neonates or young animals than in adults (Jami et al., 2013). This knowledge may translate to the intestinal microbial composition, and if so, implies that the gut microbiome may be more easily influenced during this time. This may provide the opportunity to establish beneficial bacteria during early life to decrease the possibility of pathogenic bacterial colonization and subsequent disease (Malmuthuge et al., 2015b). Feeding colostrum within the first $12 \mathrm{~h}$ of life can result in a higher prevalence of small intestinal mucosa associated Bifidobacterium and lower total E. coli compared with calves not fed colostrum (Malmuthuge et al., 2015a). However, it is unknown how the extent to which the first colostrum feeding is delayed after birth affects the bacteria colonizing the small and large intestine.

The objective of the present study was to investigate the effect of time of first colostrum feeding on the passive transfer of $\mathrm{IgG}$ and bacterial colonization in the intestine of neonatal dairy calves. We hypothesized that delaying colostrum feeding in the first $12 \mathrm{~h}$ of life would progressively decrease the passive transfer of IgG as well as the prevalence of beneficial bacteria in the small intestine (distal jejunum and ileum) and colon.

\section{MATERIALS AND METHODS}

\section{Calving and Early Calf Life}

The animal experiment was conducted following the guidelines of the Canadian Council of Animal Care (CCAC, 1993) at the Dairy Research and Technology Centre of the University of Alberta. The animal use protocol was approved by The Livestock Care Committee of the University of Alberta (AUP00001595). Approximately 3 to $10 \mathrm{~d}$ before parturition, Holstein heifers and cows were moved to maternity pens, which were bedded with fresh shavings daily and disinfected and cleaned between calvings. After the area was cleaned using 1\% iodine, an iVET birth-monitoring device (iVET, Papenburg, Germany) was inserted into the vagina. All iVET devices were thoroughly cleaned and disinfected before insertion.

Only bull calves from a singleton birth with a BW between 35 and $55 \mathrm{~kg}$ were included in the current study. Bulls were removed from the dam immediately after birth and thus there was no contact between the dam and calf. Bulls were weighed in a calibrated electronic scale (Digi-Star SW300, Digi-Star LLC, Fort Atkinson, WI) and transferred in the scale to individual pens bedded with shavings and fresh straw. Between calves, pens were thoroughly disinfected using Virkon (Lanxess Ag, Cologne, Germany) and lime. Calves were dried using 2 clean towels for $10 \mathrm{~min}$, after which calves' navels were dipped with $7 \%$ iodine.

\section{Animal Experiment and Feeding}

Male Holstein calves $(\mathrm{n}=27)$ born from February to September 2016 were randomly allocated into 3 treatment groups: calves fed colostrum at $45 \mathrm{~min}(0 \mathrm{~h}, \mathrm{n}=$ $9), 6 \mathrm{~h}(\mathrm{n}=9)$, or $12 \mathrm{~h}$ after birth $(\mathrm{n}=9)$. A single batch of pooled, heat-treated colostrum containing 62 $\mathrm{g}$ of $\mathrm{IgG} / \mathrm{L}$ was provided by the Saskatoon Colostrum Company Ltd. (Saskatoon, SK, Canada) and fed to calves at their respective feeding times at $7.5 \%$ of birth BW. Before feeding, colostrum was thawed and heated to $39^{\circ} \mathrm{C}$ in a water bath kept at a consistent temperature of $50^{\circ} \mathrm{C}$. Once heated, colostrum was poured into two 2-L esophageal tubing bottles and transferred to the calf pen in a bucket of warm $\left(\sim 39^{\circ} \mathrm{C}\right)$ water, where it was tube fed to the calf in less than 5 min. Twelve hours after their colostrum feeding, calves were fed milk replacer with a 26:18 CP:fat ratio (Excel Pro-Gro Calf Milk Replacer, Grober Nutrition, Cambridge, ON, Canada) at a volume of $2.5 \%$ of birth BW per meal every $6 \mathrm{~h}$ until euthanasia at $51 \mathrm{~h}$ after birth. Milk replacer was prepared by mixing $150 \mathrm{~g}$ of milk replacer powder in $1 \mathrm{~L}$ of water in a clean bucket, poured into a clean bottle with a unique nipple, and heated in the water bath to $39^{\circ} \mathrm{C}$. If calves did not consume the milk replacer meal within $30 \mathrm{~min}$, the remainder of the meal was fed using an esophageal tube. If calves refused more than $50 \%$ of their milk replacer intake by nipple bottle per $24 \mathrm{~h}$, they were excluded from the study.

\section{Blood Sampling}

At approximately 20 min of life, a 3-mL serum sample was collected from the jugular vein using a Vacutainer (Becton, Dickinson and Co., Franklin Lakes, NJ) to establish baseline values. At $2 \mathrm{~h}$ after birth, a 2-inch, 16 -gauge catheter was inserted into the jugular vein of each calf for the duration of its life. To insert the cath- 
eter, the calf was gently restrained by a handler and its neck was shaven and disinfected with chlorohexidine and ethanol before the catheter was inserted. Blood samples were collected every $3 \mathrm{~h}$ and left at room temperature for $3 \mathrm{~h}$ to clot; serum was collected following centrifugation at $3,000 \times g$ at $4^{\circ} \mathrm{C}$ for $20 \mathrm{~min}$. The serum was transferred into three $1.5-\mathrm{mL}$ microcentrifuge tubes in equal aliquots and frozen at $-20^{\circ} \mathrm{C}$.

\section{Intestinal Tissue and Digesta Sampling}

Intestinal samples were collected from all calves at 51 $\mathrm{h}$ of life ( $3 \mathrm{~h}$ after the final meal). Calves were euthanized with a pentobarbital sodium injection (Euthanyl, Vetoquinol, Lavaltrie, QC, Canada) at $0.125 \mathrm{~mL} / \mathrm{kg}$ of BW administered through the jugular catheter. Once the calf reached a surgical plane of anesthesia, exsanguination was performed, the rectum and esophagus were ligated, and the entire gut contents were removed. Following this, 10-cm-long intestinal segments of predefined gut regions were collected. The distal jejunum segment was defined as $30 \mathrm{~cm}$ proximal to the collateral branch of the cranial mesenteric artery; the ileum segment was defined as $30 \mathrm{~cm}$ proximal to the ileo-cecal junction; and the colon segment was defined as $30 \mathrm{~cm}$ distal to the ileo-cecal junction (Malmuthuge et al., 2015b). Intestinal content was removed from the sample using tweezers, and placed in a 50-mL Falcon tube. Then, the tissue was washed in PBS until clean $(\sim 3-4$ washes) and placed in a sterile bag. Both intestinal content and tissue samples were immediately snap-frozen in liquid nitrogen and transferred to a $-80^{\circ} \mathrm{C}$ freezer until further use.

\section{Analysis of Serum IgG}

Serum samples were thawed and centrifuged at 3,000 $\times g$ for 20 min at $4^{\circ} \mathrm{C}$, after which supernatant was transferred to a new tube. Serum samples were refrozen in $-20^{\circ} \mathrm{C}$ for $24 \mathrm{~h}$ and then shipped overnight on ice to the Saskatoon Colostrum Company quality assurance laboratory for determination of serum IgG concentrations by radial immunodiffusion analysis (Chelack et al., 1993) with modifications as described in Chamorro et al. (2014). The same method was used for determination of IgG in the single pooled colostrum batch.

The maximum apparent efficiency of absorption (AEA, \%) of IgG for each treatment group was calculated using calf birth weight, calf serum IgG concentration, and colostrum IgG mass. The formula used was previously described by Quigley et al. (2002), with the assumption of a plasma volume of $9.9 \%$ of birth weight. Parameters relative to colostrum feeding were calculated from the raw data, including time to reach maximum concentration $\left(\mathbf{T}_{\max }\right)$, maximum concentration reached $\left(\mathbf{C}_{\max }\right)$, ratio of $\mathrm{C}_{\max } / \mathrm{T}_{\max }$, change in concentration (delta change), and IgG concentrations at 12,24 , and $36 \mathrm{~h}$ after the colostrum meal $\left(\mathrm{IgG}_{12}, \operatorname{IgG}_{24}\right.$, $\left.\mathrm{IgG}_{36}\right)$. The positive incremental area under the curve (AUC) for IgG was determined using the trapezoid rule over the first $12 \mathrm{~h}\left(\mathrm{AUC}_{12}\right), 24\left(\mathrm{AUC}_{24}\right)$, and 36 $\left(\mathrm{AUC}_{36}\right) \mathrm{h}$ after birth.

\section{DNA Extraction from Tissue and Digesta Samples}

The total DNA from intestinal digesta was extracted using the repeated bead beating plus column method (Yu and Morrison, 2004). Briefly, the digesta sample $(\sim 0.3 \mathrm{~g})$ was washed twice with Tris-EDTA buffer. After the addition of cell lysis buffer containing $4 \%$ SDS, samples were subjected to physical disruption at 4,800 rpm for 3 min using Biospec Mini Beads Beater 8 (BioSpec, Bartlesville, OK), followed by incubation at $70^{\circ} \mathrm{C}$ for $15 \mathrm{~min}$ and centrifugation for $5 \mathrm{~min}$ at 16,000 $\times g$. The bead beating, incubation, and centrifugation were repeated once and impurities were removed from the supernatant using $10 \mathrm{M}$ ammonium acetate, followed by DNA precipitation using isopropanol. After precipitation, DNA was further purified using QIAmp fast DNA stool mini kit (Qiagen Inc., Germantown, MD). The quantity and purity of DNA were evaluated using NanoDrop 1000 spectrophotometer (Nanodrop Technologies, Wilmington, DE), and DNA was stored at $-20^{\circ} \mathrm{C}$ until further use. For processing of tissue samples, the tissue was ground in liquid nitrogen before DNA extraction. Approximately $0.1 \mathrm{~g}$ of the ground tissue was subjected to DNA extraction using the beadbeating method as described by Li et al. (2009). The DNA quantity and purity were evaluated as described above.

\section{Quantification of Bacterial Groups in the Calf Distal Jejunum, Ileum, and Colon Using Quantitative Real-Time PCR}

For intestinal digesta and tissue samples, the densities of total bacteria, Bifidobacterium, Lactobacillus, Clostridium cluster XIVa, Fecalibacterium prausnitzii, and total E. coli were estimated by measuring their respective $16 \mathrm{~S}$ rRNA gene copy numbers using quantitative real-time PCR. Bacterial populations from digesta samples were estimated using the StepOnePlus real-time PCR system (Applied Biosystems/ThermoFisher Scientific, Waltham, MA), and bacterial populations associated with the tissue were estimated using the high throughput Viia 7 Real-Time PCR System 
Table 1. Bacterial primers $(\mathrm{F}=$ forward; $\mathrm{R}=$ reverse) used to determine the copy number of $16 \mathrm{~S}$ rRNA genes in the calf intestine

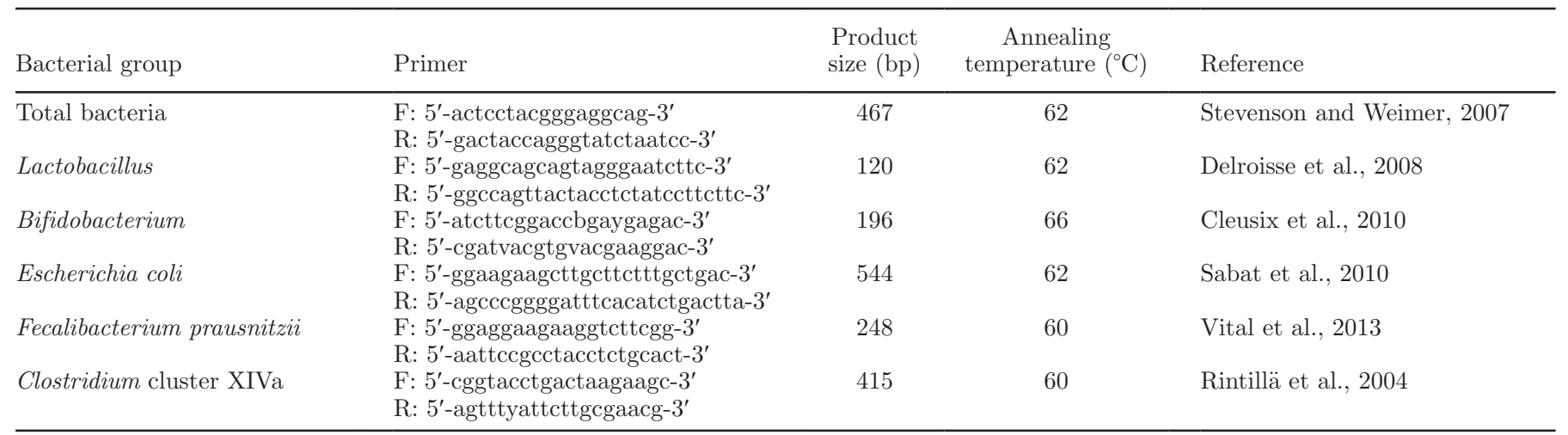

(Thermo-Fisher Scientific). For both tissue and digesta, PCR was performed using SYBR Green chemistry (Fast SYBR Green Master Mix, Applied Biosystems, Foster City, CA) with specific primers targeting each bacterial group (Table 1). Standard curves were generated for each bacterial group using purified 16S rRNA genes of Butyrivibrio hungatei, Bifidobacterium adolescentis, Lactobacillus acidophilus ATCC4356, Roseburio hominis A2-183, Fecalibacterium prausnitzii A2-165, and Escherichia coli K12, respectively. The copy number of $16 \mathrm{~S}$ rRNA genes per gram of digesta or tissue was calculated using the equation described by Li et al. (2009). The proportion of each bacterial group was obtained and defined as copy number per gram of each bacterial group divided by the copy number per gram of total bacteria (Malmuthuge et al., 2015b). The prevalence (\% of total bacteria) was determined by multiplying the proportion by 100 .

\section{Statistical Analysis}

To determine the effect of colostrum treatment, all data were analyzed using the MIXED procedure of SAS software (version 9.4, SAS Institute Inc., Cary, NC). For serum IgG concentrations and AEA, repeated measures were used with the model, including the fixed effects of treatment, age, and treatment by age interaction. For IgG parameters calculated relative to the meal, as well as the $\mathrm{AEA}_{\max }$, only the colostrum treatment was included as a fixed effect. For the prevalence and copy number of $16 \mathrm{~S}$ rRNA gene per gram for the bacterial groups, data were analyzed by colostrum treatment by bacterial target (Bifidobacterium, Lactobacillus, total E. coli, Clostridium cluster XIVa, F. prausnitzii, and total bacteria), by type (tissue, content) within each region of the intestine (distal jejunum, ileum, colon). All values reported are least squares means with significance declared at $P \leq 0.05$ and tendencies at 0.05 $<P<0.10$.

\section{RESULTS}

\section{Effect of Delaying Colostrum Feeding on Passive Transfer of IgG}

Feeding colostrum within the first hour of life $(0 \mathrm{~h})$ increased the passive transfer of IgG compared with feeding colostrum at 6 and $12 \mathrm{~h}$ of life (Figure 1; Table 2 ). Calves fed at $0 \mathrm{~h}$ had a higher AUC for the first $12 \mathrm{~h}$ after the colostrum meal $\left(\mathrm{AUC}_{12}\right)$ compared with 6-h and 12-h calves (Table 2). Similarly, 0 -h calves had higher $\mathrm{AUC}_{24}$ and $\mathrm{AUC}_{36}$ compared with 6 -h and 12 -h calves. We detected no difference in passive transfer in 6-h and 12-h calves. In general, calves fed at $0 \mathrm{~h}$ had significantly higher mean concentrations of $\mathrm{IgG}(\mathrm{mg} /$ $\mathrm{mL}$ ) for the first $27 \mathrm{~h}$ of life than 6 -h and 12 -h calves (Figure 1).

Calves fed at $0 \mathrm{~h}$ of life displayed a $28.0 \%$ increase in $\mathrm{C}_{\max }$ compared with 6-h and 12 -h calves, whereas no difference was detected between 6 - $\mathrm{h}$ and 12 -h groups (Table 2). In addition, $\mathrm{AEA}_{\max }$ was $32.4 \%$ higher in $0-\mathrm{h}$ calves compared with 6 -h and 12 -h calves. No differences were observed among treatments for $\mathrm{T}_{\max }$ relative to the colostrum meal (Table 2).

\section{Effect of Delaying Colostrum Feeding on Bacteria Associated with Mucosa}

In general, high variation was observed between calves for the copy number of $16 \mathrm{~S}$ rRNA genes per gram of fresh sample for both mucosa- and digestaassociated bacterial groups. Calves fed at $6 \mathrm{~h}$ tended to have a lower $(P=0.08)$ total bacteria density associated with the distal jejunum mucosa than those fed at $0 \mathrm{~h}$, whereas no differences were detected between 0 -h and 12-h calves (Figure 2). The prevalence of F. prausnitzii associated with the distal jejunum mucosa was higher in 12 -h calves $(P=0.06)$ and 6 -h calves $(P=$ 0.04 ) than in calves fed immediately after birth (Table 


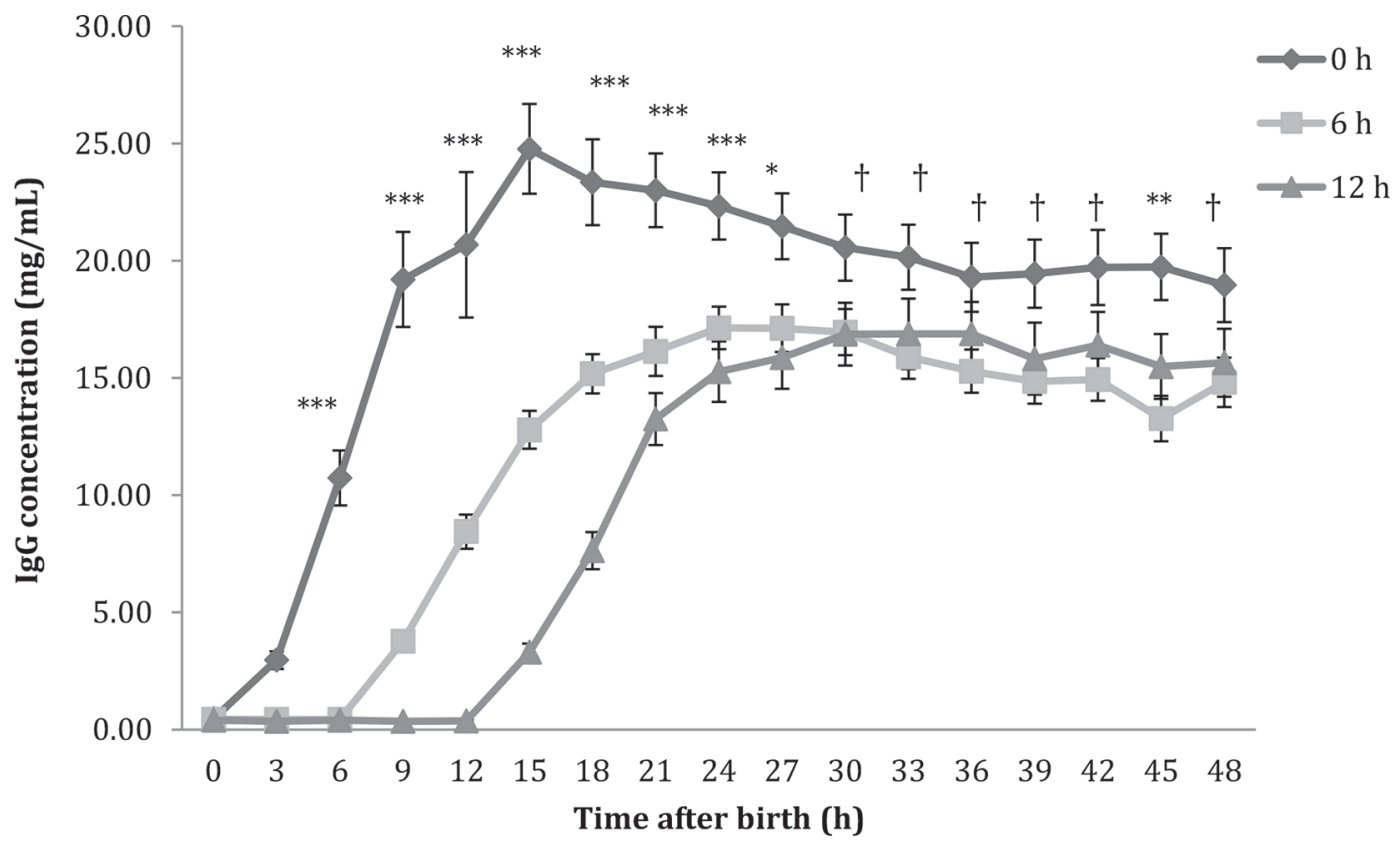

Figure 1. The effect of delaying colostrum feeding by 0 (fed within first hour of life), 6 , or $12 \mathrm{~h}$ on serum concentrations of $\mathrm{IgG}$ (mg/mL) relative to time of birth. Points represent mean \pm SEM. ${ }^{* * *} P<0.001,{ }^{* *} 0.001<P<0.01,{ }^{*} 0.01<P<0.05, \dagger 0.05<P<0.10$.

3). No further differences among treatment groups were detected in the bacterial groups associated with the mucosa of the distal jejunum.

In the ileum, a $33.3 \%$ decrease $(P=0.08)$ in F. prausnitzii associated with the mucosa was observed in 6-h calves compared with 0 -h calves, whereas no differences were detected between 12 -h and 0 -h calves. Moreover, a lower prevalence of $E$. coli was associated with the ileum mucosa when calves were fed colostrum at $6 \mathrm{~h}(P$ $=0.05)$ and $12 \mathrm{~h}(P=0.09)$ compared with calves fed colostrum at $0 \mathrm{~h}$ (Table 3 ).

In regards to bacterial groups associated with the mucosa of the colon, 12-h calves tended to have a lower prevalence of Bifidobacterium $(P=0.08)$ and Lactobacillus $(P=0.05)$ than 0 -h calves, whereas no differences were observed between 0 -h and 6 -h calves for

Table 2. Calf characteristics (mean \pm SEM) among treatment groups and the effect of delaying colostrum feeding on IgG parameters relative to ingestion of first colostrum meal ${ }^{1}$

Delay in colostrum feeding (h)

\begin{tabular}{|c|c|c|c|c|}
\hline \multirow[b]{2}{*}{ Parameter $^{1}$} & & \multirow[b]{2}{*}{$P$-value } \\
\hline & 0 & 6 & 12 & \\
\hline Birth BW (kg) & $43.5 \pm 1.51$ & $42.0 \pm 1.74$ & $42.2 \pm 0.96$ & 0.324 \\
\hline $\operatorname{IgG}$ intake $(\mathrm{g})$ & $202.3 \pm 7.02$ & $195.3 \pm 8.09$ & $196.1 \pm 4.49$ & 0.618 \\
\hline Baseline serum IgG $(\mathrm{mg} / \mathrm{mL})$ & $0.4 \pm 0.17$ & $0.4 \pm 0.10$ & $0.38 \pm 0.04$ & 0.902 \\
\hline $\mathrm{AEA}_{\max }(\%)$ & $51.8 \pm 4.18^{\mathrm{a}}$ & $35.6 \pm 1.88^{\mathrm{b}}$ & $35.1 \pm 3.15^{\mathrm{b}}$ & 0.007 \\
\hline $\mathrm{AUC}_{12}$ & $130.4 \pm 14.20^{\mathrm{a}}$ & $98.4 \pm 5.90^{\mathrm{b}}$ & $96.0 \pm 7.60^{\mathrm{b}}$ & 0.038 \\
\hline $\mathrm{AUC}_{24}$ & $408.3 \pm 35.00^{\mathrm{a}}$ & $297.8 \pm 16.00^{\mathrm{b}}$ & $293.1 \pm 22.30^{\mathrm{b}}$ & 0.006 \\
\hline $\mathrm{AUC}_{36}$ & $657.2 \pm 50.60^{\mathrm{a}}$ & $483.7 \pm 26.30^{\mathrm{b}}$ & $485.0 \pm 38.40^{\mathrm{b}}$ & 0.006 \\
\hline $\operatorname{IgG}_{12}(\mathrm{mg} / \mathrm{mL})$ & $23.2 \pm 2.00^{\mathrm{a}}$ & $15.2 \pm 0.80^{\mathrm{b}}$ & $15.3 \pm 1.30^{\mathrm{b}}$ & 0.001 \\
\hline $\mathrm{IgG}_{24}(\mathrm{mg} / \mathrm{mL})$ & $22.3 \pm 1.40^{\mathrm{a}}$ & $17.0 \pm 1.00^{\mathrm{b}}$ & $16.9 \pm 1.40^{\mathrm{b}}$ & 0.008 \\
\hline $\mathrm{IgG}_{36}(\mathrm{mg} / \mathrm{mL})$ & $19.3 \pm 1.50^{\mathrm{a}}$ & $14.9 \pm 0.90^{\mathrm{b}}$ & $15.6 \pm 1.40^{\mathrm{b}}$ & 0.058 \\
\hline $\mathrm{T}_{\max }(\mathrm{h})$ & $17.0 \pm 0.71$ & $21.0 \pm 1.22$ & $20.7 \pm 2.03$ & 0.111 \\
\hline $\mathrm{C}_{\max }(\mathrm{mg} / \mathrm{mL})$ & $25.5 \pm 2.00^{\mathrm{a}}$ & $18.2 \pm 1.10^{\mathrm{b}}$ & $18.5 \pm 1.40^{\mathrm{b}}$ & 0.003 \\
\hline $\mathrm{C}_{\max } / \mathrm{T}_{\max }(\mathrm{mg} / \mathrm{mL}$ per hour $)$ & $1.5 \pm 0.13^{\mathrm{a}}$ & $1.2 \pm 0.90^{\mathrm{b}}$ & $1.0 \pm 0.14^{\mathrm{b}}$ & 0.003 \\
\hline Delta change $(\mathrm{mg} / \mathrm{mL})$ & $25.0 \pm 2.03^{\mathrm{a}}$ & $17.8 \pm 1.08^{\mathrm{b}}$ & $18.1 \pm 1.34^{\mathrm{b}}$ & 0.004 \\
\hline
\end{tabular}

${ }_{\mathrm{a}, \mathrm{b}}$ Means within a row with different letters are significantly different at $P<0.05$.

${ }^{1} \mathrm{AEA}_{\max }=$ maximum apparent efficiency of absorption; $\mathrm{AUC}_{12}, \mathrm{AUC}_{24}, \mathrm{AUC}_{36}=$ area under the curve during the first 12, 24, and $36 \mathrm{~h}$ after colostrum feeding, respectively; $\operatorname{IgG}_{12}, \mathrm{IgG}_{24}, \mathrm{IgG}_{36}=$ immunoglobulin $\mathrm{G}$ concentration at 12,24 , and $36 \mathrm{~h}$ after the colostrum feeding; $\mathrm{T}_{\max }=$ time to maximum concentration; $\mathrm{C}_{\max }$ $=$ maximum concentration. 
these genera (Figure 3). No differences were detected among treatment groups with regards to the prevalence of Clostridium cluster XIVa, F. prausnitzii, or total E. coli in the colon mucosa-associated microbiota.

\section{Effect of Delaying Colostrum Feeding on Bacteria Associated with Digesta}

Compared with mucosa-associated bacteria, fewer differences were detected in the bacterial groups associated with intestinal digesta. In the distal jejunum digesta, 12-h calves displayed a lower $(P=0.04)$ prevalence of $E$. coli than 0 -h calves (Table 4$)$. In the ileum digesta, there was a tendency $(P=0.09)$ for a higher prevalence of Clostridium cluster XIVa in 6-h calves than in 0 - $\mathrm{h}$ calves, whereas no differences were observed between 12-h and 0-h calves. Similarly, 6-h calves tended $(P=0.09)$ to have a higher prevalence of Clostridium cluster XIVa in the colon digesta than 0-h calves. No differences were observed for total bacteria (Figure 2), Bifidobacterium, Lactobacillus, or F. prausnitzii prevalence in the intestinal digesta among treatment groups.

\section{DISCUSSION}

To our knowledge, the present study is the first to determine how a delay in colostrum feeding using current colostrum feeding recommendations, highly standardized colostrum, and frequent blood sampling affects the passive transfer of $\operatorname{IgG}$ in the neonatal calf. We hypothesized that delaying the first colostrum meal would progressively decrease the passive transfer of IgG in neonatal calves. In accordance with our hypothesis,
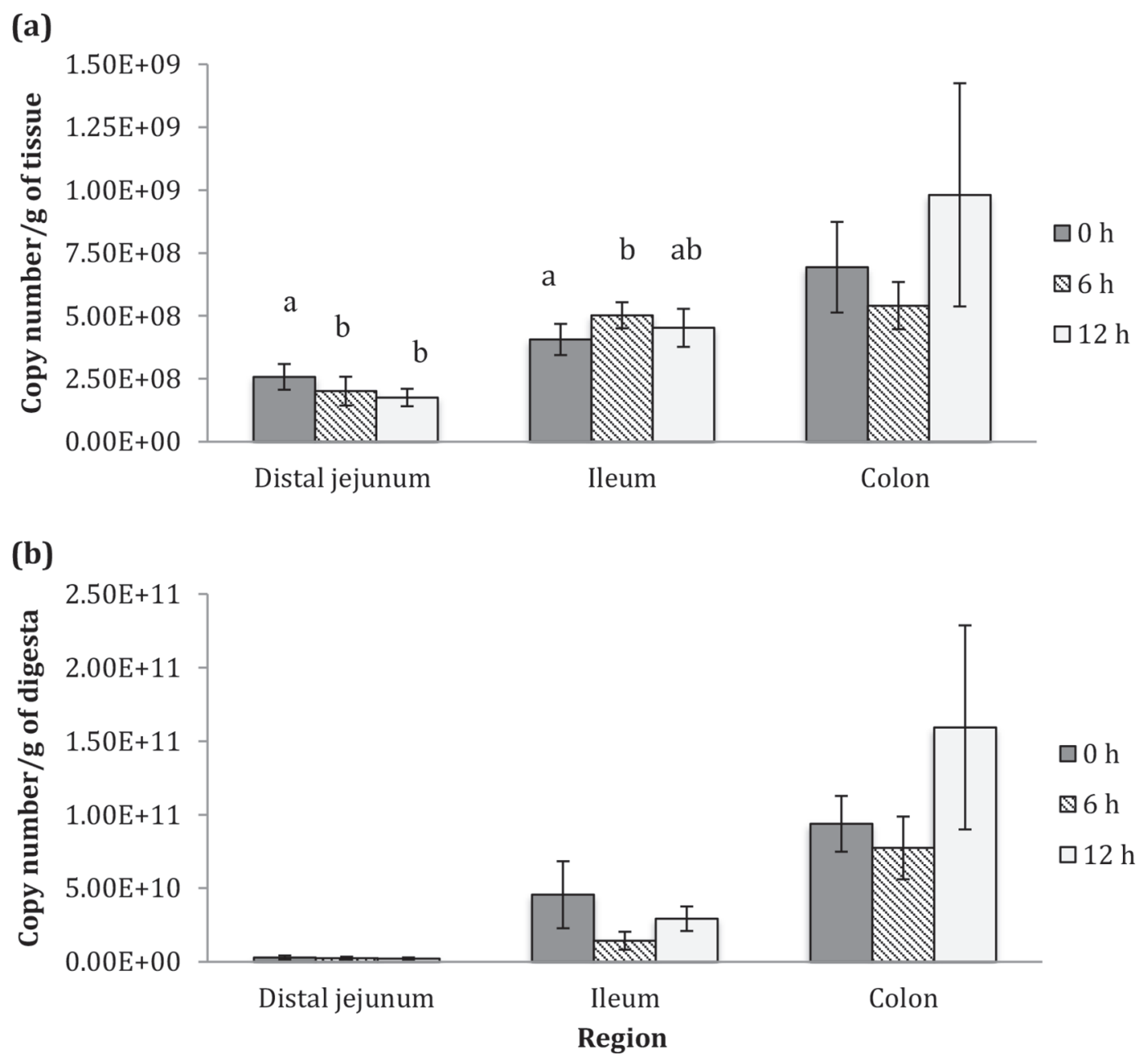

Figure 2. Effect of delaying colostrum feeding (by 0,6 , or $12 \mathrm{~h}$ ) on number of copies of $16 \mathrm{~S}$ rRNA genes of total bacteria associated with (a) the mucosa and (b) the digesta of the distal jejunum, ileum, and colon of neonatal calves at $51 \mathrm{~h}$ of life. Bars represent mean \pm SEM. Different letters $(\mathrm{a}, \mathrm{b})$ indicate that the average number of copies of $16 \mathrm{~S}$ rRNA genes of total bacteria tended to be different within each intestinal region among treatment groups $(0.05<P<0.10)$. 
feeding colostrum immediately after birth increased the maximum concentration of serum IgG reached, as well as the apparent efficiency of absorption of $\operatorname{IgG}$ compared with calves fed colostrum at 6 or $12 \mathrm{~h}$ after birth. The increased absorption of IgG demonstrated by calves fed within the first hour of life was consistent with previous reports, which stated that IgG transfer across the enterocyte is optimal within the first $4 \mathrm{~h}$ after birth (Stott et al., 1979). Moreover, 0-h calves displayed a peak in IgG absorption at approximately $15 \mathrm{~h}$ of life (Figure 1), which is different from earlier studies that report maximal levels at $24 \mathrm{~h}$ (Stott et al., 1979). The current study found peak serum levels at 24 h only for 6 -h- and 12-h-fed calves. However, peak IgG concentrations may have been observed at $15 \mathrm{~h}$ for $0-\mathrm{h}$ calves in the current study because only one meal of colostrum was fed to calves, instead of 2 meals, which would provide a prolonged supply of IgG. Regardless, this is an important finding that deserves further consideration and study because many sampling protocols for passive transfer experiments have relied upon the view that peak serum IgG levels occur $24 \mathrm{~h}$ after birth, irrespective of the time of the first feeding. After reaching maximum $\operatorname{IgG}$ concentration at $15 \mathrm{~h}$ of life, $0-\mathrm{h}$ calves displayed a progressive decrease and plateau in serum IgG concentrations. Colostral IgG infused into the duodenum of neonatal piglets can be transported into the lymph (Kiriyama, 1992), and similar mechanisms have been reported in the calf (Balfour and Comline, 1962; Staley et al., 1972; Weaver et al., 2000). Therefore, this may explain this decrease and plateau of IgG in 0 -h calves. If IgG is indeed being recycled and absorbed into the lymphatic system from the blood, this likely leaves calves fed colostrum immediately after birth better protected against pathogenic challenges they encounter in early life compared with calves fed colostrum later.

Contrary to our hypothesis, no differences were found in IgG parameters relative to colostrum feeding for calves fed at $6 \mathrm{~h}$ and $12 \mathrm{~h}$ of life, demonstrating that these delays do not progressively decrease the absorption of $\mathrm{IgG}$. These findings are in contrast to earlier studies that reported a linear decline in absorption over this same period (White, 1993). The result of our study suggests that there may be a critical time point between 1 and $6 \mathrm{~h}$ of life when the closure of the small intestine progresses to a finite degree. Previous studies demonstrated the presence of a tubular vesicle-vacuolar mechanism in neonatal enterocytes, with the number of vacuoles that transport IgG from the intestinal lumen to the blood decreasing over time as the gastrointestinal tract matures (Kraehenbuhl and Campiche, 1969; Ockleford and Whyte, 1980; Smeaton and Simpson-Morgan, 1985; Louis and Lin, 2009). The 

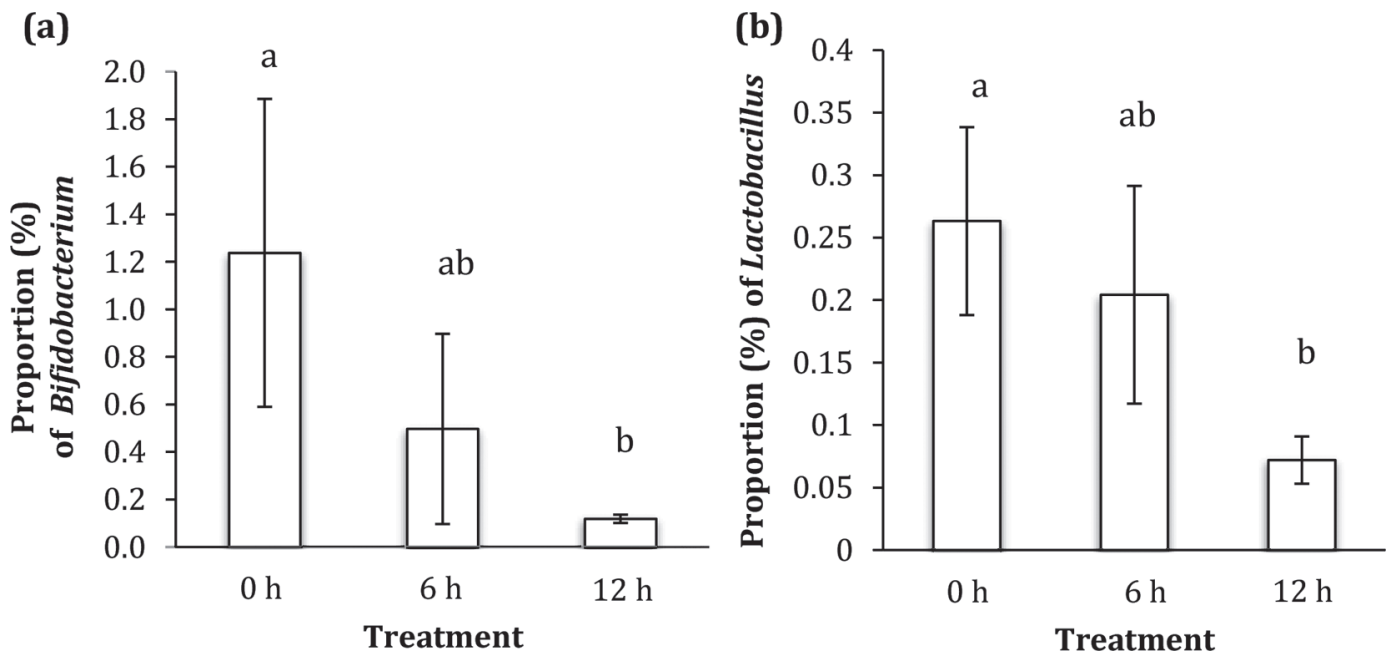

Figure 3. Effect of delayed colostrum feeding (by 0,6 , or $12 \mathrm{~h}$ ) on the prevalence (\% of total bacteria) of (a) Bifidobacterium, and (b) Lactobacillus associated with the colon mucosa of neonatal calves at $51 \mathrm{~h}$ of life. Bars represent mean \pm SEM. Different letters (a, b) indicate a tendency to differ among treatments at $0.05<P<0.10$.

reduced ability of 6 -h and 12 -h calves to absorb $\operatorname{IgG}$ as efficiently as 0-h calves may be due to the turnover of fetal intestinal cells into mature enterocytes with a decreased ability to absorb IgG from colostrum (Smeaton and Simpson-Morgan, 1985). Early studies also suggest that a hormonal influence might be involved in closure of the small intestine, as it has been reported that when the first colostrum meal is delayed, calves experience a "cortisol shock," which may induce changes in the absorptive capacity of the intestine (Kruse and Buus, 1972; Nightengale, 1979). However, other reports found no relationship between glucocorticoid concentrations and absorption of IgG (Stott and Reinhard, 1978; Johnston and Oxender, 1979), thus leaving this mechanism still to be elucidated.

The exact mechanism by which passive transfer and closure occurs has not been demonstrated and findings are conflicting. The majority of studies concerning delayed colostrum feeding, the absorption of IgG, and its effect on calf endocrinology and intestinal cell development were conducted more than $30 \mathrm{yr}$ ago, when recommendations for the volume and quality of colostrum within the first hours of life were less stringent than they are today. As well, in older studies, the colostrum fed was often not standardized and blood was taken less frequently than in the present experiment, which may have affected the reported hormone concentrations, specifically that of cortisol, due to large diurnal variations (Gardy-Godillot et al., 1989). Thus, the factors causing reduced IgG absorption in calves not fed colostrum until 6 or $12 \mathrm{~h}$ of life, or later, remain to be elucidated, and further research using current recom- mendations of colostrum quality and volume, as well as frequent blood sampling, is needed.

The gut microbial community plays a key role in developing the immune system, utilizing nutrients, and influencing the overall physiology of the host (Mazmanian et al., 2005; Peterson et al., 2007). In the current study, calves fed colostrum at $12 \mathrm{~h}$ after birth tended to have a lower prevalence of Bifidobacterium and Lactobacillus associated with the colon mucosa than calves fed colostrum immediately after birth. Species belonging to these genera are considered beneficial bacteria, because they produce lactic acid and short-chain fatty acids, which have trophic and regulatory effects on colonocytes (Boffa et al., 1992; Cummings, 1995). A study conducted by Malmuthuge et al. (2015a) determined that feeding colostrum to neonatal calves increased the prevalence of Bifidobacterium and total bacteria in the small intestine within the first $12 \mathrm{~h}$ of life compared with calves not fed colostrum. The delay in the delivery of colostral nutrients for $12 \mathrm{~h}$ after birth in the present study likely affected microbial dynamics during early life by shifting the establishment of certain bacterial groups to correspond with the timing of the delivery of nutrients. Preventing the immediate initiation of the growth and establishment of beneficial genera may have lasting effects on the dynamic bacterial community in the large intestine and hinder the ability of the gut to face challenges later in life, such as neonatal calf diarrhea (Oikonomou et al., 2013). However, a potential limitation of the present study was the assessment of intestinal bacterial groups at only one time point after birth. We speculate that sampling at an earlier time 
(e.g., at $24 \mathrm{~h}$ of life) may have provided conclusive evidence in regards to the effect of delayed colostrum feeding on colonization of beneficial intestinal bacteria in the intestine. Therefore, we believe that future research should focus on the microbial community dynamics as this delay occurs, using dissection at frequent intervals as well as control calves not fed colostrum.

In addition, although some microorganisms are beneficial to health, others may be harmful (Picard et al., 2005). For example, enterotoxigenic E. coli (ETEC) K99, Cryptosporidium parvum, and rotavirus account for $5.5,55.0$, and $58.7 \%$ of diarrhea incidence in preweaning calves, respectively (Uhde et al., 2008). Pathogenic E. coli, including ETEC K99, typically binds to the ileum and colon (Orskov et al., 1975; Corley et al., 1977; Moxley and Francis, 1986). Therefore, the lower prevalence of total $E$. coli associated with the ileum mucosa in 6 -h and 12 -h calves compared with 0 -h calves was not expected in the present study. Malmuthuge et al. (2015a) demonstrated that calves not fed colostrum within $12 \mathrm{~h}$ after birth displayed a significantly lower density (copy of $16 \mathrm{~S}$ rRNA gene/g of sample) of total bacteria than calves fed fresh or heat-treated colostrum soon after birth, suggesting that bacterial colonization occurs at a slower rate in the absence of colostrum feeding. On the other hand, in mammals, generic E. coli can also benefit the host by preventing the colonization of pathogenic bacteria (Reid et al., 2001), producing vitamin $\mathrm{K}_{2}$ (Sharma et al., 1992), and limiting the growth of competitive bacteria in the inflamed intestine (Sassone-Corsi et al., 2016). In the current study, the prevalence of total $E$. coli was measured, and further research is needed to determine whether the lower prevalence of total E. coli in 6-h and 12-h calves involved beneficial or pathogenic species. We speculate that the lower prevalence of $E$. coli in 6 -h and 12 -h calves was due to the delay in the delivery of colostral nutrients to this bacterial group in the intestine.

Many of the bacterial groups associated with the mucosa and digesta of the distal jejunum, ileum, and colon did not exhibit any statistical differences among treatment groups. This may be due to the large individual variation in regards to the detected copy number of the $16 \mathrm{~S}$ rRNA gene per gram of fresh sample. High genetic, microbial, and transcriptomic variation in the neonatal calf has been reported previously, with the exact reasoning for the variation not yet determined (Liang et al., 2014; Malmuthuge et al., 2015a). The specific microbial environment of the birth canal of the dam and the site of parturition may have an effect on the phenotype, as well as the nutrition provided to the animal. Regardless of the exact causative factors for this high individual variation, the neonatal calf intestine - devoid of microorganisms before birth - is at this time undergoing 
unfamiliar, dynamic microbial changes. The newborn microbiome is only just beginning to establish itself, and thus the microbes within each individual would be expected to interact with the host in a unique way, leading to the observed high individual variation.

\section{CONCLUSIONS}

Delaying colostrum feeding by 6 or $12 \mathrm{~h}$ after birth decreased the passive transfer of IgG and the time to maximum serum $\operatorname{IgG}$ concentration compared with feeding colostrum immediately after birth. We speculate that the gut decreases in permeability when colostrum is not fed immediately to newborn calves; however, the exact mechanism by which this occurs is unknown and warrants further investigation. Delaying colostrum feeding tended to decrease the prevalence of beneficial bacteria associated with the colon mucosa, specifically Bifidobacterium and Lactobacillus spp., which play important roles in gut health. How the presence of these specific bacterial groups during the first days of life may affect future growth and productivity needs to be explored further.

\section{ACKNOWLEDGMENTS}

The authors thank the funding support provided by Alberta Livestock and Meat Agency Ltd., Alberta Milk, The Saskatoon Colostrum Co. Ltd. and the Natural Sciences and Engineering Research Council of Canada. The authors also thank the staff of the Dairy Research and Technology Centre (University of Alberta) for their assistance with the animal experiment, as well as $\mathrm{R}$. Kong (University of Alberta) for her assistance with laboratory analysis.

\section{REFERENCES}

Apgar, G. A., E. T. Kornegay, M. D. Lindemann, and C. M. Wood. 1993. The effect of feeding various levels of Bifidobacterium globosum $\mathrm{A}$ on the performance, gastrointestinal measurements, and immunity of weanling pigs and on the performance of carcass measurements of growing-finishing pigs. J. Anim. Sci. 71:2173-2179.

Balfour, W. E., and R. S. Comline. 1962. Acceleration of the absorption of unchanged globulin in the new-born calf by factors in colostrum. J. Physiol. 160:234-257.

Boffa, L. C., J. R. Lupton, and M. R. Mariani. 1992. Modulation of colonic epithelial cell proliferation, histone acetylation, and luminal short chain fatty acids by variation of dietary fibre (wheat bran) in rats. Cancer Res. 52:5906-5912.

CCAC. 1993. Guide to the Care and Use of Experimental Animals. Vol. 1. E. D. Olfert, B. M. Cross, and A. A. McWilliams, ed. Canadian Council on Animal Care, Ottawa, ON, Canada.

Chamorro, M. F., P. H. Walz, D. M. Haines, T. Passler, T. Earleywine, R. A. Palomares, K. P. Riddell, P. Galik, Y. Zhang, and M. D. Givens. 2014. Comparison of levels and duration of detection of antibodies to bovine viral diarrhea virus 1 , bovine viral diarrhea virus 2 , bovine respiratory syncytial virus, bovine herpesvirus 1 , and bovine parainfluenza virus 3 in calves fed maternal colostrum or a colostrum-replacement product. Can. J. Vet. Res. 78:81-88.

Chelack, B. J., P. S. Morley, and D. M. Haines. 1993. Evaluation of methods for dehydration of bovine colostrum for total replacement of normal colostrum in calves. Can. Vet. J. 34:407-412.

Cleusix, V., C. Lacroix, G. Dasen, M. Leo, and G. Le Bay. 2010. Comparative study of a new quantitative real-time PCR targeting the xyulose-5-phosphate/fructose-6-phosphate phosphoketolase bifidobacterial gene $(\mathrm{xfp})$ in faecal samples with two fluorescence in situ hybridization methods. J. Appl. Microbiol. 108:181-193. https:// doi.org/10.1111/j.1365-2672.2009.04408.x.

Corley, L. D. T. E. Staley, L. J. Bush, and E. W. Jones. 1977. Influence of colostrum on transepithelial movement of Escherichia coli 055. J. Dairy Sci. 60:1416-1421.

Cummings, J. H. 1995. Short chain fatty acids. Pages 101-130 in $\mathrm{Hu}-$ man Colonic Bacteria: Role in Nutrition, Physiology, and Pathology. G. R. Gibson and G. T. MacFarlane, ed. CRC Press, Boca Raton, FL.

Delroisse, J. M., A. L. Boulvin, I. Parmentier, R. D. Dauphin, M. Vandenbol, and D. Portetelle. 2008. Quantification of Bifidobacterium spp. and Lactobacillus spp. in rat fecal samples by real-time PCR. Microbiol. Res. 163:663-670.

Gardy-Godillot, M., D. Durand, M. Dalle, and D. Bauchart. 1989. Diurnal pattern of plasma cortisol in preruminant calves fasted or fed different milk proteins. J. Dairy Sci. 72:1842-1846.

Godden, S. 2008. Colostrum management for dairy calves. Vet. Clin. North Am. Food Anim. Pract. 24:19-39. https://doi.org/10.1016/ j.cvfa.2007.10.005.

Guarner, F. 2006. Enteric flora in health and disease. Digestion 73:512.

Jami, E., A. Israel, A. Kotser, and I. Mizrahi. 2013. Exploring the bovine rumen bacterial community from birth to adulthood. ISME J. 7:1069-1079.

Johnston, N. E., and W. D. Oxender. 1979. Effect of altered serum glucocorticoid concentrations on the ability of the newborn calf to absorb colostral immunoglobulin. Am. J. Vet. Res. 40:32.

Kiriyama, H. 1992. Enzyme-linked immunoabsorbent assay of colostral IgG transported into lymph and plasma in neonatal pigs. Am. J. Physiol. 263:R976-R980.

Kraehenbuhl, J. P., and M. A. Campiche. 1969. Early stages of intestinal absorption of specific antibodies in the newborn. An ultrastructural, cytochemical and immunological study in the pig, rat and rabbit. J. Cell Biol. 42:345-365.

Kruse, V., and O. Buus. 1972. Corticosteroids in cow and calf at parturition. Acta Vet. Scand. 13:585.

Li, M., G. B. Penner, E. Hernandez-Sanabria, M. Oba, and L. L. Guan. 2009. Effects of sampling location and time, and host animal on assessment of bacterial diversity and fermentation parameters in the bovine rumen. J. Appl. Microbiol. 107:1924-1934. https://doi .org/10.1111/j.1365-2672.2009.04376.x.

Liang, M., N. Malmuthuge, T. B. McFadden, H. Bao, P. J. Griebel, P. Stothard, and L. L. Guan. 2014. Potential regulatory role of microRNAs in the development of bovine gastrointestinal tract during early life. PLoS One 9:e92592.

Louis, N. A., and P. W. Lin. 2009. The intestinal immune barrier. NeonReviews 10:e180-e190.

Malmuthuge, N., Y. Chen, G. Liang, L. A. Goonewardene, and L. L. Guan. 2015b. Heat-treated colostrum feeding promotes beneficial bacteria colonization in the small intestine of neonatal calves. J. Dairy Sci. 98:8044-8053.

Malmuthuge, N., P. J. Griebel, and L. L. Guan. 2015a. The gut microbiome and its potential role in the development and function of newborn calf gastrointestinal tract. Front. Vet. Sci. 2:36.

Mazmanian, S. K., C. H. Liu, A. O. Tzianabos, and D. L. Kasper. 2005. An immunomodulatory molecule of symbiotic bacteria directs maturation of the host immune system. Cell 122:107-118.

Moxley, R. A., and D. H. Francis. 1986. Natural and experimental infection with an attaching and effacing strain of Escherichia coli in calves. Infect. Immun. 53:339-346. 
Nightengale, G. T. 1979. The effects of delayed feeding on serum corticoid concentrations and their relationship to immunoglobulin absorption in the calf. MSc Thesis. University of Arizona, Tucson.

Ockleford, C. D., and A. Whyte. 1980. Coated Vesicles. Cambridge University Press, Cambridge, UK.

Oikonomou, G., A. G. V. Tiexeria, C. Foditsch, M. L. Bicalho, V. S. Machadon, and R. C. Bicalho. 2013. Fecal microbial diversity in pre-weaned dairy calves as described by pyrosequencing of metagenomic 16S rDNA. Association of Faecalibacterium species with health and growth. PLoS One 8:e63157.

Orskov, I., F. Orskov, H. W. Smith, and W. J. Sojka. 1975. The establishment of K99, a thermolabile, transmissible Escherichia coli K antigen, previously called "Kco", possessed by calf and lamb enteropathogenic strains. Acta Pathol. Microbiol. Scand. B 83:31-36.

Peterson, D. A., N. P. McNulty, J. L. Guruge, and J. I. Gordon. 2007. IgA response to symbiotic bacteria as a mediator of gut homeostasis. Cell Host Microbe 2:328-339.

Picard, C., J. Fioramonti, A. Francois, T. Robinson, F. Neant, and C. Matuchansky. 2005. Review article: Bifidobacteria as probiotic agents-Physiological effects and clinical benefits. Aliment. Pharmacol. Ther. 22:495-512.

Quigley, J. D., 3rd, C. J. Kost, and T. M. Wolfe. 2002. Absorption of protein and IgG in calves fed a colostrum supplement or replacer. J. Dairy Sci. 85:1243-1248.

Reid, G., J. Howard, and B. S. Gan. 2001. Can bacterial interference prevent infection? Trends Microbiol. 9:424-428.

Rintillä, T., A. Kassinen, E. Malinen, L. Kroguis, and A. Palva. 2004. Development of an extensive set of $16 \mathrm{~S}$ rDNA targeted primers for quantification of pathogenic and indigenous bacteria in faecal samples by real-time PCR. J. Appl. Microbiol. 97:1166-1177. https://doi.org/10.1111/j.1365-2672.2004.02409.x.

Sassone-Corsi, M., S.-P. Nuccio, H. Liu, D. Hernandez, C. T. Vu, A. A. Takahashi, R. A. Edwards, and M. Raffatellu. 2016. Microcins mediate competition among Enterobacteriaceae in the inflamed gut. Nature 540:280-283.

Sabat, G., P. Rose, W. J. Hickey, and J. M. Harkin. 2000. Selective and sensitive method for PCR amplification of Escherichia coli $16 \mathrm{~S}$ rRNA genes in soil. Appl. Environ. Microbiol. 66:844-849.

Sharma, V., K. Suvarna, R. Meganathan, and M. E. S. Hudspeth. 1992. Menaquinone (vitamin K2) biosynthesis: Nucleotide sequence and expression of the menB gene from Escherichia coli. J. Bacteriol. 174:5057-5062.

Smeaton, T. C., and M. W. Simpson-Morgan. 1985. Epithelial cell renewal and antibody transfer in the intestine of the foetal and neonatal lamb. Aust. J. Exp. Biol. Med. Sci. 63:41-51.
Sommer, F., and F. Bäckhed. 2013. The gut microbiota-Masters of host development and physiology. Nat. Rev. Microbiol. 11:227-238.

Staley, T. E., L. D. Corley, L. J. Bush, and E. W. Jones. 1972. The ultrastructure of neonatal calf intestine and absorption of heterologous proteins. Anat. Rec. 172:559-579.

Stevenson, D. M., and P. J. Weimer. 2007. Dominance of Prevotella and low abundance of classical ruminal bacterial species in the bovine rumen revealed by relative quantification real-time PCR. Appl. Microbiol. Biotechnol. 75:165-174.

Stott, G. H., D. B. Marx, B. E. Menefee, and G. T. Nightengale. 1979. Colostral immunoglobulin transfer in calves I. Period of absorption. J. Dairy Sci. 62:1632-1638.

Stott, G. H., and E. J. Reinhard. 1978. Adrenal function and passive immunity in the dystocial calf. J. Dairy Sci. 61:1457.

Uhde, F. L., T. Kaufmann, H. Sager, S. Albini, R. Zanoni, E. Schelling, and M. Meylan. 2008. Prevalence of four enteropathogens in the faeces of young diarrhoeic dairy calves. Vet. Rec. 163:362-366.

USDA. 2007. National Animal Health Monitoring System: Dairy. Heifer calf health and management practices on U.S. dairy operations. USDA Animal and Plant Health Inspection Service, Veterinary Services, Ft. Collins, CO.

Vasseur, E., F. Borderas, R. I. Cue, D. Lefebvre, D. Pellerin, J. Rushen, K. M. Wade, and A. M. de Passille. 2010. A survey of dairy calf management practices in Canada that affect animal welfare. J. Dairy Sci. 93:1307-1315. https://doi.org/10.3168/jds.2009-2429.

Vital, M., C. R. Penton, Q. Wang, V. B. Young, D. A. Antonopoulos, M. L. Sogin, H. G. Morrison, L. Raffals, E. B. Chang, G. B. Huffnagle, T. M. Schmidt, J. R. Cole, and J. M. Tiedje. 2013. A gene-targeted approach to investigate the intestinal butyrateproducing bacterial community. Microbiome 1:8. https://doi.org/ 10.1186/2049-2618-1-8.

Weaver, D. M., J. W. Tyler, D. C. VanMetrem, D. E. Hostetler, and G. M. Barrington. 2000. Passive transfer of colostral immunoglobulins in calves. J. Vet. Intern. Med. 14:569-577.

Wells, S. J., D. A. Dargatz, and S. L. Ott. 1996. Factors associated with mortality to 21 days of life in dairy heifers in the United States. Prev. Vet. Med. 29:9-19.

White, D. G. 1993. Colostral supplementation in ruminants. Compend. Contin. Educ. Pract. Vet. 15:335-342.

$\mathrm{Yu}, \mathrm{Z}$., and M. Morrison. 2004. Improved extraction of PCR-quality community DNA from digesta and fecal samples. Biotechniques $36: 808-812$. 